\title{
WAFATNYA SUAMI DAN ISTRI SEBAGAI SYARAT PEMBAGIAN WARIS SUKU MUNA DI BALIKPAPAN SELATAN: TINJAUAN HUKUM SYARIAH
}

\author{
Sri Hartati \\ Sekolah Tinggi Ilmu Syariah (STIS) Hidayatullah Balikpapan \\ srihartatic89@gmail.com \\ Nadhrota Na'imi Nurul Hayati \\ Sekolah Tinggi Ilmu Syariah (STIS) Hidayatullah Balikpapan \\ nadhrotanurul@gmail.com
}

\begin{abstract}
Abstrak
Ketentuan hukum waris dalam Islam terkait pembagian dan peralihan hak waris dapat terjadi apabila seorang wafat dan meninggalkan harta juga ahli waris, sedangkan menurut hukum waris adat khususnya pada suku Muna di Balikpapan Selatan menerapkan syarat pembagian waris apabila pasangan suami dan istri telah wafat. Tulisan ini bertujuan melakukan studi tentang sistem pembagian waris suku Muna di Balikpapan Selatan. Adapun yang menjadi faktor dari berbedanya pembagian waris bagi Suku Muna yaitu adanya ketentuan adat yang wajib dilaksanakan, dengan pembagian tersebut maka terdapat manfaat yang akan diperoleh ahli waris dan keluarga, di antaranya tidak membebani dan memecah belah hubungan para ahli waris, serta bentuk penghormatan kepada salah satu pasangan yang ditinggal wafat.
\end{abstract}

\section{Keyword: Waris, Suku Muna, Syarat, Adat}

\section{A. Pendahuluan}

Islam memiliki konsep penyelesaian dalam berbagai problematika, karena syariat dan dasar-dasar ajarannya mencakup segala hukum bagi segala peristiwa yang tidak terbatas. ${ }^{1}$ Salah satu yang diatur dalam syariat Islam adalah hukum kewarisan. Allah yang Maha Adil tidak melalaikan dan mengabaikan hak setiap ahli waris. ${ }^{2}$ Ketentuan dengan ditetapkannya harta kepemilikan bagi setiap manusia dengan cara yang berlaku. ${ }^{3}$

Berdasarkan hukum Islam dalam menguraikan prinsip-prinsip hukum kewarisan, satu-satunya sumber tertinggi dalam kaitan ini adalah al-Qur'an dan sebagai pelengkap yang menjabarkannya adalah Sunnah Rasul beserta hasil-hasil ijtihad atau upaya para ahli hukum Islam. ${ }^{4}$

Hukum kewarisan Islam adalah hukum yang mengatur segala sesuatu yang berkenaan dengan peralihan hak atau kewajiban atas harta kekayaan seseorang

\footnotetext{
1 Yazid bin 'Abdul Qadir Jawaz, Prinsip Dasar Islam Menurut al-Quran dan as-Sunnah yang Sahīh (Bogor: Pustaka At-Taqwa, 2005), 26.

2 Dian Khairul Umam, Fiqih Mawāris (Bandung; CV. Pustaka Setia, 1999), 43.

3 Muhammad Ali As-Sahabuni, Al-Mawāris Fisy Syarī'ati; Islāmiyyah 'Alā Dhaul Kitāb was Sunnah, trans. A.M. Basalamah (Jakarta: Gema Insani Press, 1995), 32.

${ }^{4}$ Eman Suparman, Hukum Waris Indonesia (Bandung: PT. Refika Aditama, 2007), 11.
} 
setelah ia meninggal dunia kepada ahli warisnya. Dengan demikian, dalam hukum kewarisan ada tiga unsur pokok yang saling terkait yaitu pewaris, harta peninggalan, dan ahli waris. Kewarisan pada dasarnya merupakan bagian yang tak terpisahkan dari hukum, sedangkan hukum adalah bagian dari aspek ajaran Islam yang pokok. ${ }^{5}$

Hal ini berbanding terbalik dengan fenomena yang terjadi pada masyarakat suku Muna di Balikpapan Selatan yang hingga saat ini mayoritas menggunakan hukum adat dalam persyaratan pembagian waris. Hasil temuan data diperoleh suatu ketentuan, yakni ketika seorang suami meninggal, maka istri yang ditinggal wafat memiliki kendali kuasa terhadap harta waris yang ditinggalkan suaminya sebagai orang yang mewariskan. Sehingga istri berhak memutuskan ketentuan akan harta waris, ingin dipergunakan, dibagikan kepada ahli waris atau menyimpannya.

Selanjutnya, apabila anak yang ditinggalkan ingin mendapatkan harta warisan, maka harus menunggu hingga sang ibu atau istri yang ditinggal wafat suami meninggal dunia dulu. Masalah ini berlaku serupa ketika sang istri meninggal dunia lebih awal, maka harus menunggu sang ayah atau suami yang ditinggal mati istri meninggal dunia pula.

Pandangan ini jelas tidak sejalan dengan hukum Islam yang memandang bahwa tiap orang punya hak atas hartanya masing-masing. ${ }^{6}$ Sebagaimana yang telah ditetapkan dalam hukum faraid, sebab permasalahan tersebut akan berdampak kepada ahli waris selain dari istri, yang semesetinya ada hak dari harta warisan menjadi tidak mendapatkan diwaktu yang semesetinya karena tertangguhkan.

\section{B. Metode Penulisan}

Penulisan adalah Penulisan lapangan (Field Research), yang bersifat deskriptif analitik. Lokasi Penulisan ini tepatnya berada di Kelurahan Sepinggan Raya, kecamatan Balikpapan Selatan, Kota Balikpapan, Kalimantan Timur. Subjek Penulisan ini adalah warga suku Muna yang berdomisili di Balikpapan Selatan, adapun objek peneliatian ini yaitu wafatnya suami dan istri sebagai syarat pembagian waris suku muna di Balikpapan Selatan. Sehingga membutuhkan data berupa identitas informan, terdiri dari: tempat tanggal lahir, alamat, riwayat hidup dan pekerjaan. Hasil wawancara langsung antara Penulis dan responden. Faktor-faktor yang mempengaruhi pemahaman, gambaran umum lokasi Penulisan.

${ }^{5}$ Ali Parman, Kewarisan dalam al-Quran (Suatu Kajian Hukum dengan Pendekatan Tafsir Tematik) (Jakarta: Raja Grafindo Persada, 1995).

${ }^{6}$ Ahmad Sarwat, Seri Fiqih Kehidupan: Mawāris (Jakarta: Rumah Fiqih Publishing, 2017), 15/52. 
Sumber data dalam Penulisan ini adalah subjek dimana dapat diperoleh. Yaitu orang yang merespon atau menjawab pertanyaan-pertanyaan yang diajukan Penulis. Adapun sumber data yang Penulis gunakan sebagai berikut: Sumber data primer, data yang langsung diperoleh dari sumbernya. Sumber data sekunder, data yang diperoleh dari Informan berupa website atau situs internet. Sumber data tersier, dilakukan dengan melakukan kajian pustaka berupa; buku-buku literatur, artikel, jurnal dan informasi lain yang dapat dipertanggungjawabkan.

Pengumpulan data dengan beberapa teknik, yaitu: observasi, dokumentasi, dan wawancara. Kemudian pengelolaan data dengan teknik kategorisasi, matrikasi data dan editing. Terakhir yaitu tahapan analisis dengan cara reduksi data, verifikasi, penarikan kesimpulan. Analisis kualitatif yang menggunakan metode induktif yaitu bagaimana cara pembagian waris masyarakat suku Muna yang menjadi responden dalam Penulisan ini, serta bagaimana ketetapan hukum Islam akan pendapat mereka. Sehingga mempermudah bahasan dan dipahami secara mudah.

\section{Konsep Waris}

Kajian waris dalam hukum Islam, merupakan wujud dari salah satu entitas pembahasan ilmu fiqih yang esensial. Sebab itulah para ahli fiqih telah menelaah yang bertautan dengan warisan, kemudian ditorehkan pada karya-karya mengenai waris ini, dan diimplementasikan pada sebuah ilmu yang berdiri secara singular yang dinamakan dengan ilmu fiqih mawaris atau ilmu faraid.

Kata al-mawārīs (المواريث) ialah bentuk jamak atau majemuk dari al-mīrās (الميراث). Dalam bahasa Arab al-mīrās adalah bentuk masdar dari kata (ورث - يرث - إرثا - ومير اثن).7 Dalam interpretasinya menurut bahasa ialah:

$$
\text { انتقال الشيء من قوم إلى قوم آخرين. }
$$

Artinya: "Berpindahnya sesuatu dari seseorang kepada orang lain, atau dari suatu kaum kepada kaum yang lain."8

Pengertian menurut bahasa ini bukanlah terbatas hanya pada hal-hal yang bertautan dengan harta dan non harta benda. Kata waris termaktub dalam berbagai konfigurasi, makna tersebut dapat kita temukan dalam al-Qur'an, yang antara lain, mengganti kedudukan (Q.S. an-Naml [27]: 16), memberi atau menganugerahkan (Q.S. az-Zumar [39]: 74), dan mewarisi atau meminta warisan (Q.S. Maryam [19]: 6). ${ }^{9}$

7 Komite Fakultas Syariat Universitas al-Azhar, Ahkāmul Mawāris fil Fiqhil Islāmi, trans. Addys Aldizar dan Faturrahman (Mesir: Senayan Abadi Publishing, 2004), 71.

${ }^{8}$ Abdul Karim ibn Muhammad al-Lahim, al-Faraidh (Saudi Arabia: Wizarat al-Syu'un al-Islamiyati wa al-Auqaf wa al-Da'wah wa al-Irsyad, 2000), 2.

${ }_{9}^{9}$ Ahmad Rofiq, Fikih Mawaris (Depok: PT. Raja Grafindo Persada, 2000), 40. 
Di Indonesia penyebutan fiqih al-mawārīs (ilmu waris) disebut juga hukum kewarisan Islam, hukum warisan, hukum kewarisan dan hukum waris, yang sebenarnya terjemahan bebas dari kata mawaris. Bedanya, fiqih al-mawārīs menunjukkan identitas hukum waris Islam, sementara hukum warisan memiliki konotasi umum, bisa mencakup hukum waris adat atau hukum waris yang diatur dalam kitab undang-undang hukum perdata. ${ }^{10}$

Kompilasi Hukum Islam pasal 171 ayat a, menyatakan bahwa hukum kewarisan adalah hukum yang mengatur tentang perpindahan hak pemilikan harta peninggalan (tirkah) pewaris, menentukan anggota keluarga yang berhak menjadi ahli waris dan berapa bagian setiap individunya. ${ }^{11}$

Faraid adalah bentuk jamak dari faridah, yang merupakan kata turunan dari fardu. Sedangkan dalam istilah ulama mawaris fardu merupakan anasir tertentu bagi para ahli waris yang telah dikukuhkan oleh syara' seperti setengah (an-nisyfu), seperempat (ar-rubu'), seperdelapan (as-sumun), dua pertiga (as-sulusain), sepertiga (as-sulus), dan seperenam (as-sudus).

Berpijak pada pengertian di atas dan dapat dikatakan sebagai pembagian waris yang sah, maka menghasilkan tiga rukun waris yang harus terpenuhi. Jika salah satu dari ketiga hukum rukun tersebut tidak ada, maka pewarisan tidak dapat dilaksanakan. ${ }^{12}$ Rukun-rukun tersebut ialah:

1. Al-Muwarris (ألمورّث) pewaris, adalah mayat yang meninggalkan harta atau hak yang dapat diwarisi oleh ahli waris, baik mati hakiki maupun mati hukmi (suatu kematian yang dinyatakan oleh keputusan hakim atas dasar beberapa sebab, kendati sebenarnya ia belum mati tetapi meninggalkan hak atau harta). ${ }^{13}$

2. Al-Waris (الوارث), adalah orang yang berhak mendapat bagian dari warisan mayat karena ada salah satu sebab yang tiga, yaitu ikatan nasab (darah/kekerabatan/ketururnan), ikatan perkawinan, atau pun ikatan membebaskan hamba sahaya. Walaupun terdapat ahli waris yang terhalang (terhijab) atau sebab yang melarangnya. ${ }^{14}$ Diartikan juga bahwa ahli waris adalah orang yang pada saat meninggal dunia mempunyai hubungan darah

${ }^{10}$ Ahmad Rofiq, Fiqih Mawāris, (Jakarta: Raja Grafindo Persada, 2001), 4.

11 Tim Redaksi Nuansa Aulia, Kompilasi Hukum Islam, 81.

12 Ibid.

13 Komite Fakultas Syariat Universitas al-Azhar, Ahkāmul Mawāris fil Fiqhil Islāmi, trans. Addys Aldizar dan Faturrahman, 27.

14 M. Ataillah, Fikih Waris Metode Pembagian Waris Praktis (Bandung: Penerbit Yrama Widya, 2018), 19-20. 
atau perkawinan dengan pewaris, beragama Islam, dan tidak terhalang karena hukum untuk menjadi ahli waris. ${ }^{15}$

3. Al-Maurus (لهوروث), yaitu harta benda yang ditinggalkan oleh mayit dan menjadi warisan, seperti uang, tanah, dan lain-lain. Termasuk dalam kategori warisan adalah hak-hak yang mungkin dapat diturunkan, seperti hak perdata (qisas), hak menahan barang yang belum dilunasi pembayarannya, dan hak menahan barang gadaian. ${ }^{16}$ Sebagian ulama faraid menyebutkan warisan dengan sebutan al-irs, at-turās, al-miras, dan attarikah keseluruhannya memiliki artian yang sama. ${ }^{17}$ Tetapi tidak semua harta yang dianggap miliki pewaris bisa dialokasikan sebagai harta warisan. Terdapat beberapa syarat, antara lain harta tersebut merupakan harta yang sah dan legal milik pewaris atau dapat dikatakan, bukan harta yang tercampur dengan harta milik orang lain. Sebelum harta tersebut dibagikan kepada ahli waris, terlebih dahulu mengeluarkan segala kewajiban mayit, termasuk biaya penyelenggaraan untuk memandikan jenazah, mengkafankan, mensalatkan, dan menguburkan. ${ }^{18}$

Kelangsungan pewarisan dapat terjadi dengan tiga syarat yang harus terpenuhi, berkaitan dengan orang yang meninggal atau pewaris dan ahli waris. Ketiga syarat tersebut yaitu:

1. Meninggalnya orang yang mewariskan. Kematiannya baik secara sejati, menurut putusan hukum, atau menurut perkiraan. Hal ini disebabkan, selama manusia masih hidup ia berhak mengelola hartanya dan kepemilikannya masih tetap, sehingga ia tidak boleh digantikan oleh orang lain. Jika ia sudah wafat, maka ia tidak berdaya sama sekali untuk mengelola harta kekayaan yang menjadi miliknya sehingga hilanglah hak kepemilikannya dan berpindah kepada ahli waris. ${ }^{19}$

2. Adanya ahli waris yang hidup. Ahli waris diketahui masih hidup secara haqiqi dengan menyaksikan langsung, terdapat berita yang telah masyhur, atau dengan persaksian dua orang yang dapat dipercaya. Berkaitan ahli waris adalah orang yang akan mewakili posisi pewaris dan kepemilikan

15 Ahmad Sarwat, Seri Fiqih Kehidupan [15]: Mawāris, 97-98.

16 Komite Fakultas Syariat Universitas al-Azhar, Ahkāmul Mawāris fil Fiqhil Islāmi, trans. Addys Aldizar dan Faturrahman, 28.

17 Muhammad Ali al-Sabouni, Al-Mawāris fisy Syarī'ah al-Islāmiyyah, trans. Hamdan Rasyid (Jakarta: Dar al-Kutb al-Islamiyah, 2005), 49.

18 Ahmad Sarwat, Seri Fiqih Kehidupan [15]: Mawāris, 97.

${ }^{19}$ Muhammad Ali al-Sabouni, Al-Mawāris fisy Syarīah al-Islāmiyyah, trans. Hamdan Rasyid, 49. 
harta beralih kepadanya melalui prosedur kewarisan, maka ketika pewaris wafat ia harus benar-benar dalam kondisi hidup. ${ }^{20}$

3. Mengetahui sebab menerima harta warisan. Ahli waris wajib mengetahui keberadaan dirinya dalam menerima waris disebabkan garis kekerabatan, perkawinan, atau perwalian. Pengetahuan tentang silsilah hak mewarisi secara terperinci, tidak serta-merta dapat dijadikan dasar pewarisan atas suatu harta. ${ }^{21}$

Islam telah menyediakan aturan terkait hukum pewarisan yang mengandung kebaikan serta keadilan. Tujuan ilmu waris adalah memberikan hak kepada orang yang berhak dari harta peninggalan mayit tanpa mendiskriminasi suatu kalangan. Hal lain dengan adanya ilmu waris diketahui kepada siapa dan seberapa besar bagian yang diterima oleh ahli waris tersebut. Selain itu, potensi pengamalan ayat-ayat alQur'an yang membahas masalah ini, menyelamatkan harta orang yang meninggal dari pihak yang tidak bertanggung jawab, mengetahui syarat dan rukun waris, mengetahui sebab-sebab pewarisan, menghindari perselisihan antara ahli waris atau keluarga yang ditinggalkan, serta memahami asas-asas hukum kewarisan Islam.

Keutamaan ilmu waris ini besar. Dinyatakan bahwa ilmu faraid adalah setengah dari ilmu, karena ia berkaitan dengan kondisi manusia setelah dirinya wafat, sebagaimana semua muamalah berhubungan dengannya saat masih hidup. Nabi Muhammad saw bersabda,

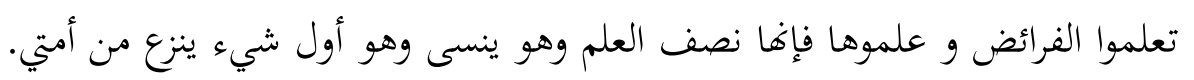

"Belajarlah ilmu faraid dan ajarkanlah. Sesungguhnya ia adalah setengah dari ilmu. Ilmu ini akan dilupakan, dan ia adalah hal pertama yang dicabut dari umatku."22

Segala sesuatu memuat hikmah, nilai, dan amanat bagi individu maupun masyarakat. Demikian pula dengan adanya pelaksanaan hukum waris, banyak mengandung hikmah bagi individu yang menerima maupun orang-orang di sekitarnya. Di antara banyak hikmah tersebut ialah keberadaan persamaan hak, keadilan bagi setiap ahli waris, mempererat persaudaraan, dan menjauhkan insan dari sifat kikir dan serakah.

20 M. Ataillah, Fikih Waris Metode Pembagian Waris Praktis, 21.

${ }^{21}$ Komite Fakultas Syariat Universitas al-Azhar, Ahkāmul Mawāris fil Fiqhil Islāmi, trans. Addys Aldizar dan Faturrahman, 31.

22 Muhammad bin Ali bin Muhammad bin 'Abdillah bin al Husain Asy-Syaukani, Nailul Autar Syarh Muntaqa al-Akhbar (Damaskus: Idarah at-taba'ah al-Munirah, n.d.), 4/53. 


\section{Dasar Hukum Waris Islam}

Islam menetapkan ayat al-Qur'an, hadits Nabi, dan ijma' tentang kewarisan sebagai sumber hukum penetapan tata cara pembagian waris berdasarkan hikmah dengan pembagian terbaik dan teradil. Al-Qur'an merupakan sumber hukum waris yang banyak menjelaskan tuntunan bagian (fard) setiap ahli waris, seperti terkandung dalam surah an-Nisa ayat 7, 11, 12, 176, dan surah-surah lainnya. Sebagai halnya dipaparkan dalam ayat waris. ${ }^{23}$ Firman Allah swt dalam Q.S. An Nisa ayat 7:

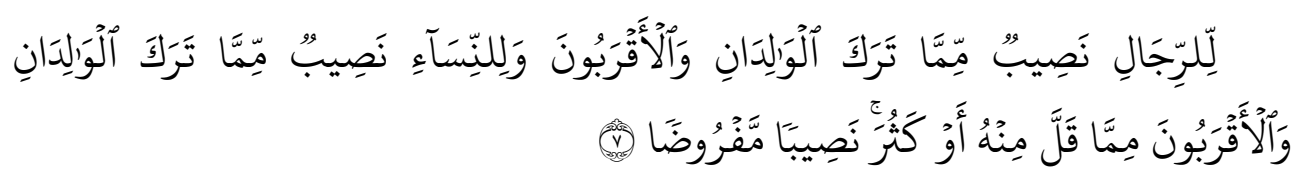

"Bagi orang laki-laki ada hak bagian dari harta peninggalan ibu-bapa dan kerabatnya, dan bagi orang wanita ada hak bagian (pula) dari harta peninggalan ibu-bapa dan kerabatnya, baik sedikit atau banyak menurut bahagian yang telah ditetapkan."

Sumber kedua adalah sunnah atau hadis yaitu apa-apa yang bersumber dari Rasulullah saw, baik perkataan, perbuatan, dan ketetapan. ${ }^{24}$ Hadis ini merupakan salah satu basis yang dipakai oleh umat Islam dalam menyelenggarakan beraneka macam tingkah laku, baik yang berkaitan dengan urusan dunia maupun akhirat.

Hadis sebagai sumber hukum agama Islam yang kedua setelah kitab suci alQur'an. Jika suatu ihwal tidak diuraikan di dalam al-Qur'an, maka umat Islam akan merujuk pada sumber yang kedua yaitu hadis. Pada hal ini terdapat beberapa hadis yang menerangkan perihal pembagian waris, antara lain hadis Nabi dari Ibnu 'Abbas,

$$
\text { عن ابن عباس عن النبي صلى الله عليه وسلم قال: ألحقوا الفرائض بأهلها، فما بقي فهو لأولى رجل ذكر. }
$$

"Dari Ibnu 'Abbas a dari Nabi saw, beliau bersabda: berikanlah harta warisan (faraid\{) kepada orang-orang yang berhak menerimanya (menurut ketentuan). Bila masih ada sisa diberikan kepada saudara laki-laki terdekat."25

Sumber hukum dalam syariat yang ketiga setelah al-Qur'an dan as-Sunnah adalah ijma', karena terdapat beberapa hal yang tidak ada ketetapannya oleh syariat baik al-Qur'an dan as-Sunnah. ${ }^{26}$ Ijma' dapat dikatakan sebagai kesepakatan para

23 Dian Khair al-Umam, Fiqih Mawaris (Bandung: Pustaka Setia, 1999), 11.

24 'Abdul Wahab Khalaf, 'Ilmu Ushul Fiqh trans. Halimuddin, (Jakarta: PT. Rineka Citra, 1993), 17.

${ }^{25}$ Muhammad bin 'Ismail bin Ibrahim bin al-Mugirah al-Bukhari, Sahih Bukhari, Bab Mirasul Walad min Abihi wa Ummihi (Beirut: Da>r an-Najah, 1942), no. 6732, 8/150.

${ }^{26} \mathrm{Abu}$ 'Abdillah Muhammad bin 'Ismail al-Bukhari, Sahih Bukhari (Beirut: an-Najah, 1442), 8/150. 
mujtahid umat ini sepeninggal Nabi saw mengenai hukum syar'i. ${ }^{27}$ Para sahabat, tabi'in (generasi pasca sahabat), dan tabiut tabi'in (generasi pasca tabi'in), telah berijma' atau beritikad tentang validitas ilmu faraid dan tak seorang pun yang mengingkari ijma' tersebut. ${ }^{28}$

\section{E. 'Urf dalam Ilmu Waris}

Secara etimologi 'urf berarti sesuatu yang dipandang baik dan diterima oleh akal sehat, sedangkan secara terminologi, istilah 'urf berarti; "Sesuatu yang lazim bagi suatu masyarakat karena telah menjadi kebiasaan dan melekat dengan kehidupan mereka baik berupa perbuatan atau perkataan". ${ }^{29}$ Dalam kamus ushul fiqih, 'urf dijelaskan:

$$
\text { فرق بين العرف والعادة. }
$$

“'Urf adalah apa yang dikenal oleh manusia dan berlaku padanya, baik berupa perkataan, perbuatan ataupun meninggalkan sesuatu. Dan ini juga dinamakan adat. Dan dikalangan ulama syariat tidak ada perbedaan antara 'urf dan adat."30

Menurut ahli syara', tidak ada perbedaan antara adat dengan 'urf. Adat perbuatan, seperti kebiasaan jual beli dengan menukar barang langsung, tanpa akad dalam bentuk ucapan. Adat perkataan ialah kebiasaan menyebut al-walad adalah anak laki-laki, bukan diperuntukkan bagi anak perempuan, adat terbentuk dari kebiasaan manusia menurut derajat mereka, secara umum maupun tertentu. ${ }^{31}$ Kata 'urf berasal dari kata 'arafa yang memiliki bentuk turunan, yaitu al-Ma'ruf dengan arti sesuatu yang dikenal atau diketahui. Ilmu ushul fiqih mengenai pengertian adat dan 'urf mempunyai peran yang cukup signifikan. ${ }^{32}$

\section{Macam-macam 'Urf}

Para ulama ushul membagi 'urf menjadi tiga macam, yakni dalam segi objek, cakupan, dan keabsahannya dalam pandangan hukum. Adapun penjelasannya sebagai berikut:

27 Muhammad bin Salih al-'Utsaimin, Al-Ushul min 'Ilmil-'Ushul, trans. Ahmad S. Marzuqi, (Yogyakarta: Media Hidayah, 2008), 100.

${ }^{28}$ Komite Fakultas Syariat Universitas al-Azhar, Ahkāmul Mawāris fil Fiqhil Islāmi, trans. Addys Aldizar dan Faturrahman, 20.

${ }^{29}$ Satria Effendi, Ushul Fiqh, (Jakarta: Kencana Prenada Media Group, 2008), 153.

30 Totok Jumantoro dan Samsul Munir Amin, Kamus Ilmu Ushul Fiqih, (Jakarta: Bumi Aksara, 2009), 1.

${ }^{31}$ Abdul Wahab Khalaf, llmu Ushul Fiqih (Bandung: Pustaka Setia, 2007), 128.

32 Amir Syarifuddin, Ushul Fiqih (Jakarta: Logos Wacana Ilmu, 2001), 828/2. 
a. 'Urf dari segi objeknya dibagi menjadi dua, yaitu:

Pertama, Al-'Urf al-Lafzi adalah kebiasaan yang menyangkut ungkapan pada masyarakat yang menggunakan kebiasaan lafzi atau ungkapan tertentu dalam mengungkapkan sesuatu. ${ }^{33}$ Sebagai contoh ialah ungkapan ikan dalam masyarakat mengungkapkan lauk pauk, padahal dalam makna aslinya ialah ikan laut. Pada daerah tertentu hal ini telah umum. Apabila dalam memahami ungkapan ini memerlukan indikator lain, maka ini tidak dinamakan dengan 'urf, semisal seorang datang dalam keadaan marah dan pada tangannya terdapat tongkat kecil, kemudian ia berkata, "Jika saya bertemu dengannya, maka saya akan membunuhnya dengan tongkat ini", dari ucapan ini dipahami bahwa ia akan membunuh dengan memukulkan tongkatnya, tentu hal ini bukanlah sebuah 'urf melainkan majas. ${ }^{34}$

Kedua, al-'Urf al-'Amali, adalah kebiasaan masyarakat dalam bentuk perbuatan yang berhubungan dengan masalah keperdataan, sebagaimana kebiasaan masyarakat melakukan jual beli dengan seorang pembeli mengambil barang kemudian menuju kasir, antara sang penjual dengan sang pembeli tidak mengadakan akad dalam bentuk perkataan. ${ }^{35}$

b. 'Urf dari segi cakupannya dibagi menjadi dua, yaitu:

Pertama, Al-'Urfal-'Am, yakni kebiasaan yang bersifat umum. Kebiasaan ini adalah kebiasaan tertentu yang berlaku secara luas di seluruh masyarakat, daerah, maupun seluruh negara. ${ }^{36}$ Kedua, al-'Urf al-Khas, ialah kebiasaan yang bersifat khusus. Kebiasaan ini adalah kebiasaan yang berlaku di daerah tertentu ataupun pada hal tertentu. Sebagai contoh, penentuan masa garansi pada pembelian barang tertentu. ${ }^{37}$

c. 'Urf dari segi keabsahannya dalam pandangan hukum dibagi menjadi dua, yaitu:

Pertama, Al-'Urf al-Sahih, adalah kebiasaan yang dianggap sah. Kebiasaan ini berlaku di tengah-tengah masyarakat yang tidak bertentangan dengan nas yang tidak menghilangkan kemaslahatan mereka, dan tidak pula membawa mudarat. ${ }^{38}$ Atau dengan kata lain, tidak mengharamkan yang halal dan tidak menghalalkan yang haram. Misalnya dalam masalah pertunangan pihak laki-laki memberikan hadiah pihak wanita, maka hadiah ini tidak

\footnotetext{
33 Ibid., 364.

${ }^{34}$ Nasroen Haroen, Us $\{u>l$ Fiqih I (Jakarta: Logos Wacana Ilmu, 1997), 139.

35 Sulaliman Abdullah, Sumber Hukum Islam (Jakarta: Sinar Grafika, 1995), 78.

36 Abu Zahro, Us $\{$ u>l Fiqih (Jakarta: Pustaka Firdaus, 2911), 418.

37 Abdul Wahab Khalaf, llmu Us\{u>I Fiqih, 135.

38 Satria Efendi dan M. Zein, Us\{u>l Fiqh (Jakarta: Kencana, 2005), 154.
} 
dikatakan sebagai mahar. ${ }^{39}$

Kedua, al-'Urf al-Fasid merupakan kebiasaan yang dianggap buruk karena kebiasaan ini bertentangan dengan dalil-dalil syara' dan kaidahkaidah dasar dalam syara'. Sebagai contoh, kebiasaan yang terbiasa terjadi pada pedagang yakni riba, seperti peminjaman modal antar sesama pedagang dengan tambahan bunga sekian. ${ }^{40}$

2. Kedudukan 'Urf dalam Menentukan Hukum

Sumber hukum Islam terbagi menjadi dua, mansus (berdasarkan nas) dan gairu mans\{us (tidak berdasarkan nas). Mans\{us terbagi menjadi dua, yakni alQur'an dan as-Sunnah, sedangkan gairu mans\{us dibagi menjadi dua pula, yaitu mutaffaq 'alaih (ijma' dan qiyas) serta Mukhtalaf'alaih (istihsan, istihab, 'urf, sadd az-zara'i, maslahah mursalah, dan qaulu as-sahabi). ${ }^{41}$

Pada umumnya, 'urf ditujukan untuk memelihara kemaslahatan umat, menunjang pembentukan hukum dan penafsiran beberapa nas. Dengan 'urf dikhususkan lafal yang 'amm (umum) dan membatasi yang mutlak, karena 'urf pula terkadang qiyas ditinggalkan. Sebagian besar ulama bersepakat menerima 'urf sebagai dalil dan mengistinbat hukum, selama ia al-urf al-sahih dan tidak bertentangan dengan hukum, baik berkaitan dengan al-'urf al-'amm atau al-'urf al-khas. 'Urf dapat dijadikan sandaran untuk menetapkan suatu hukum dengan persyaratan tertentu.

Ilmu waris merupakan bagian dari kajian ilmu pengetahuan Islam, sedangkan 'urf dalam ilmu waris dibagi menjadi dua macam, yakni 'urf sahih dengan contoh harta peninggalan mayit dibagi kepada ahli waris setelah meninggalnya seseorang dengan status sebagai suami, serta 'urf fasid dengan contoh harta peninggalan mayit dibagikan kepada ahli waris ketika pasangan suami dan istri telah wafat. ${ }^{42}$

Hukum dari 'urfyang dibenarkan dalam hukum waris Islam ialah 'urfsahih, maka ada kewajiban untuk mempertahankan dan memeliharanya dalam pembentukan hukum dan peradilan. Sedangakan 'urf fasid maka tidak wajib dilaksanakan dan dipelihara karena mempertahankannya merupakan menentang dalil syar'i. ${ }^{43}$ Apabila manusia telah terbiasa dengan sistem yang di dalamnya terdapat adat yang rusak, seperti dengan hukum adat tersebut

${ }^{39}$ Abdul Wahab Khalaf, llmu Us $\{u>$ I Fiqih, 134.

40 Ibid., 135.

41 H.A. Djazuli dan I. Nurul Aen, Us\{u>l Fiqih (Metode Hukum Islam) (Jakarta: PT. Raja GrafindoPersada,2000), 186.

42 Amir Syarifuddin, Us $\{u>l$ Fiqih, 364.

43 Ibid., 370. 
manusia meyakini sebagai suatu kewajiban yang harus dilaksanakan, maka adat ini termasuk 'urf fasid. ${ }^{44}$ Adat yang telah berlangsung lama dan dapat diterima oleh masyarakat karena tidak mengandung unsur mafsadat dan tidak pula bertentangan dengan dalil syara' yang datang kemudian, maka adat ini dapat diterima oleh syariat Islam.

\section{F. Pembagian Waris Masyarakat Suku Muna}

1. Klasifikasi Data

\begin{tabular}{|c|c|c|c|c|}
\hline No. & Identitas & $\begin{array}{c}\text { Setuju terhadap } \\
\text { Meninggalnya } \\
\text { Suami dan Istri } \\
\text { Sebagai Syarat } \\
\text { Pembagian } \\
\text { Waris }\end{array}$ & \begin{tabular}{|c|} 
Tidak Setuju terhadap \\
Meninggalnya Suami \\
dan Istri Sebagai \\
Syarat Pembagian \\
Waris
\end{tabular} & Alasan \\
\hline I & LJ & $\checkmark$ & & $\begin{array}{l}\text { Harta waris } \\
\text { mayit masih } \\
\text { dipergunakan. }\end{array}$ \\
\hline II & AL & & $\checkmark$ & $\begin{array}{l}\text { Wajibnya } \\
\text { melakukan } \\
\text { pembagian } \\
\text { harta waris } \\
\text { sesuai aturan } \\
\text { agama. }\end{array}$ \\
\hline III & MD & $\checkmark$ & & $\begin{array}{l}\text { Ketentuan adat } \\
\text { yang wajib } \\
\text { dilaksanakan. }\end{array}$ \\
\hline IV & IR & $\checkmark$ & & $\begin{array}{l}\text { Hak penuh istri } \\
\text { yang ditinggal } \\
\text { wafat atas } \\
\text { harta warisan }\end{array}$ \\
\hline $\mathrm{V}$ & $\mathrm{NH}$ & $\checkmark$ & & $\begin{array}{l}\text { Anak-Anak } \\
\text { yang ditinggal } \\
\text { wafat belum } \\
\text { dewasa } \\
\text { sehingga harta } \\
\text { waris sebagai } \\
\text { nafkah }\end{array}$ \\
\hline VI & WI & $\checkmark$ & & $\begin{array}{l}\text { Tidak } \\
\text { mendoakan } \\
\text { salah satu } \\
\text { orang tua yang } \\
\text { ditinggal wafat } \\
\text { cepat } \\
\text { meninggal. }\end{array}$ \\
\hline
\end{tabular}

2. Analisis Syarat Pembagian Waris Suku Muna di Balikpapan Selatan

Berdasarkan Penulisan dan temuan data yang dipaparkan pada sub-bab 
deskripsi pendapat, Penulis menemukan adanya perbedaan dalam penerapan syarat pembagian waris pada masyarakat suku Muna di Balikpapan Selatan. Hal ini didasari pemahaman yang berbeda mengenai syarat pembagian waris. Masalah utama terkait pembagian waris dapat dilaksanakan apabila syarat tersebut terpenuhi, yakni wafatnya suami dan istri. Jika didapati salah satu pasangan dari pasangan suami dan istri belum wafat, maka kepentingan pembagian waris akan gugur karena syarat tersebut belum terpenuhi. Apabila pembagian waris terlaksana sebelum kedua suami dan istri wafat, maka dalam pandangan sebagian masyarakat suku memiliki konsekuensi yang harus ditanggung.

Melalui observasi yang Penulis lakukan serta wawancara pribadi pada keenam responden, dapat memberikan pemahaman bagaimana masyarakat suku Muna yang berada di Balikpapan Selatan melakukan pelaksanaan pembagian waris dengan syarat wafatnya suami dan istri, dalam hal ini terdapat dua muasal yang berbeda.

Pertama, wafatnya suami dan istri sebagai syarat pembagian waris masyarakat suku Muna di Balikpapan Selatan. Hal ini terjadi pada 5 pendapat responden yang Penulis dapatkan di lapangan bahwa pembagian waris tidak dapat terlaksana apabila belum didapati wafatnya kedua pasangan suami dan istri. Faktor penyebab 5 responden menyetujui pendapat ini berlandaskan alasan yang berbeda-beda.

Pendapat I menyatakan bahwa persetujuan atas syarat ini berdasar ketidakmungkinan pembagian waris dikarenakan harta waris tersebut dalam status terpakai oleh para ahli waris. Alasan lain terdapat pada pendapat III, dalam pendapatnya mengemukakan pembenaran syarat ini dengan dasar ketentuan adat telah menetapkan keharusannya dan segala sesuatu yang tetap tidak dapat diganggu gugat. Lain halnya dengan pendapat IV dalam status yang serupa terhadap keharusan memenuhi syarat pembagian waris dengan sebab kuasa atas harta peninggalan berada pada kendali salah satu pasangan yang ditinggalkan. Oleh karena itu, jikalau ingin mendapat kuasa maka harus menunggu pasangan yang ditinggal wafat pula agar perpindahan kuasa dapat terjadi.

Implementasi syarat pembagian waris dalam pemenuhannya diutarakan VI sebagai pendapatnya dengan sebab permintaan pembagian waris setelah salah satu pasangan suami istri wafat adalah sesuatu yang riskan dan kurang beradab karena menyamakan permintaan tersebut sebagai doa permintaan agar pasangan yang ditinggal wafat cepat berpulang pula.

Pendapat $\mathrm{V}$ sehaluan terhadap syarat yang harus dipenuhi sebelum 
terwujudnya pembagian waris. Dasar persetujuan syarat tersebut adalah anak keturunan ahli waris belum dewasa. Menyangkut perihal ini dapat dikatakan sebagai penangguhan waris dari salah satu pasangan yang ditinggal wafat kepada anak-anak mayit. Hal lain yang mendasarinya adalah harta peninggalan waris tersebut dipakai sebagai pemenuhan kebutuhan sehari-hari sebagai ganti nafkah, hanya saja kadar pemakaian harta waris tersebut tanpa keterangan pasti secara tertulis. Apabila harta waris tersisa ketika anak-anak mayit telah dewasa maka perpindahan kepemilikan harta waris dapat terjadi apabila pasangan mayit wafat.

Kedua, satu pendapat yang menyatakan ketidaksetujuannya terhadap wafatnya suami dan istri sebagai syarat pembagian waris suku Muna di Balikpapan Selatan. Hal yang mendasari pendapat II adalah aturan-aturan yang telah jelas ditetapkan oleh agama Islam yang universal. Aturan-aturan yang selalu menempatkan segala sesuatu pada tempatnya, jauh dari unsur kezaliman dan berlebih-lebihan.

Melihat fenomena yang terjadi di masyarakat, khususnya pada suku Muna di Balikpapan Selatan, sebab kurangnya penerapan terhadap ketentuan hukum Islam dalam persyaratan pelaksanaan pembagian harta waris mengakibatkan hal yang fatal. Pelanggaran terhadap syariat dalam pembagian waris menjadi akibatnya. Melihat dari sisi pemahaman para responden terkait aturan-aturan yang ada merupakan sebuah realitas tanpa tindakan lebih lanjut. Fenomena ini bertentangan dengan jumlah masyarakat suku dengan identitas beragama Islam sebagai mayoritas penduduk yang berdomisili di Balikpapan Selatan. Tentu berlakunya persyaratan ini menjadi kesenjangan antara idealitas dengan realitasnya.

\section{Analisis Hukum Syarat Pembagian Waris Suku Muna di Balikpapan Selatan}

Islam sebagai sebuah aturan yang integral dan ekstensif, menata segala faktor kehidupan manusia dengan tujuan tercapainya manfaat di dunia dan akhirat. Aturan Allah tentang perangai manusia secara sederhana diketahui sebagai syariat atau hukum syara' yang saat ini lebih dikenal sebagai hukum Islam. Pada bab-bab sebelumnya telah dikaji tentang persyaratan pelaksanaan atau praktik pembagian harta warisan yang dilakukan mayoritas masyarakat suku di Balikpapan Selatan yang masih percaya terhadap pelaksanaan tersebut dengan berbagai alasan.

Penulis berpendapat bahwa adat suku Muna di Balikpapan Selatan terhadap pemenuhan pembagian harta warisan dengan sebab ahli waris belum 
dewasa dapat dijadikan sumber hukum, apabila melihat dasar pengambilan manfaat dan menjaga kemaslahatan sang anak. Para ulama mazhab sepakat bahwa anak kecil dilarang menggunakan hartanya. Tetapi mereka berbeda pendapat tentang pembelanjaan harta yang dilakukan anak yang pandai. Jika akad telah sempurna dan usia balig sudah tiba, maka anak tersebut dianggap telah dewasa, sehingga semua tindakannya dalam menggunakan harta dinyatakan berlaku. Sebagaimana Allah swt berfirman dalam Q.S. an-Nisa [4]: 5,

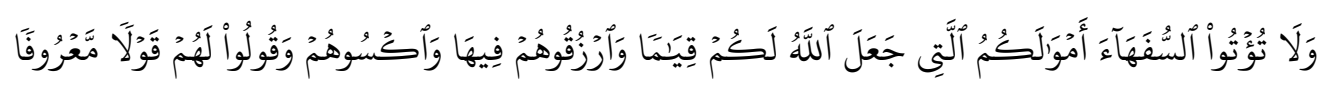

"Dan janganlah kamu serahkan kepada orang-orang yang belum sempurna akalnya, harta (mereka yang ada dalam kekuasaanmu) yang dijadikan Allah sebagai pokok kehidupan. Berilah mereka belanja dan pakaian (dari hasil harta itu) dan ucapkanlah kepada mereka kata-kata yang baik."

Maksud dari ayat tersebut dalam kitab tafsir Fi Zilalil Qur'an karya Sayyid Quthb mengemukakan bahwa orang yang belum sempurna akalnya ialah anak kecil, anak yatim, anak yang belum balig atau orang dewasa yang tidak dapat mengatur harta bendanya.

Pada tingkatan ini Penulis berpendapat bahwa kebiasaan yang terjadi dalam masyarakat suku Muna di Balikpapan Selatan ini dalam penahanan pembagian harta warisan termasuk 'urf al-shahih yaitu kebiasaan yang berlaku di tengah-tengah masyarakat yang tidak bertentangan dengan nas yakni al-Qur'an dan Sunnah, tidak menghilangkan kemaslahatan dan tidak pula mendatangkan kemudaratan. Tetapi terjadi kelanjutan dari hal ini, yaitu perpindahan kepemilikan harta mengharuskan wafatnya salah satu pasangan yang ditinggal mati, tentu sebagai sesuatu yang dianggap melanggar syariat. Sebagaimana sabda Nabi saw dari Abdullah bin 'Abbas,

$$
\text { أقسم المال بين أهل الفرائض على كتاب الله. }
$$

"Bagilah harta pusaka diantara ahli waris menurut kitab Allah." (HR. Muslim)45 Penahanan sementara harta waris anak belum dewasa yang ditinggal wafat salah satu orang tuanya merupakan hal positif yang mengandung suatu kemaslahatan, tetapi tujuan akhir yang dicapai berakhir pada suatu mafsadat, maka persyaratan pembagian waris seperti ini termasuk dalam kategori saddu alzari'ah (سد الذريعة). Sebagaimana pengertian saddu al-zari'ah yang dikemukakan

45 Imam Muslim, Sahih Muslim (Kairo: Darul Hadits, 2001), no. 1615, 59. 
oleh Imam al-Syatibi sebagai berikut:

$$
\text { التوسل بما هو مصلحة إلى مغسدة. }
$$

“Melakukan suatu pekerjaan yang semula mengandung kemaslahatan untuk menuju suatu kemafsadatan."

Juga sebagaimana dalam kaidah,

$$
\text { درء المفاسد مقدم على جلب المصالح. }
$$

"Menolak mafsadah didahulukan daripada memperoleh maslahah."46

Apabila menghadapi mafsadah pada waktu yang sama, maka harus mendahulukan mafsadah yang berdampak paling ringan akibatnya. Apabila berkumpul antara mafsadah dengan maslahah, maka pilihan terbaik adalah memilih maslahah yang paling besar atau banyak dan paling kuat maslahahnya, tetapi apabila sama banyak atau kuatnya maka menolak mafsadah lebih utama daripada menggapai maslahah, sebab menolak mafsadah tersebut telah dikatakan suatu maslahah.

Adapun persyaratan pembagian waris yakni kewajiban mengikuti adat, mendoakan orang tua yang ditinggal wafat segera menyusul wafat pula, serta pemahaman kebaikan berakibat petaka merupakan ilmu yang tidak mendasar dan pemikiran yang salah kaprah. Permintaan pembagian waris disegerakan merupakan solusi agar tidak bercampurnya harta pewaris satu dengan yang lainnya atau penundaan yang terjadi menyebabkan adanya ahli waris yang tidak mendapatkan haknya. Tentu saja tanpa disadari hal ini merupakan taqlid buta dalam hal pemahaman serta perbuatan yang telah dilarang oleh agama. Masyarakat mengikuti tradisi tanpa mengetahui asas yang dibenarkan Islam. Sebagaimana pengertian taqlid ialah mengikuti suatu tanpa mengetahui dalil.

Syariat Islam tidak membenarkan taqlid terhadap sesuatu tanpa adanya dalil yang mendasarinya. Hal ini jelas diharamkan untuk dilakukan, karena tidak sesuai dengan ketentuan Islam. Jika suatu hal tidak diketahui, dianjurkan untuk bertanya kepada para ahli pada bidang permasalahan tersebut agar tidak jatuh dalam taqlid. Sebagaimana tercantum dalam Q.S. An-Nahl: 43,

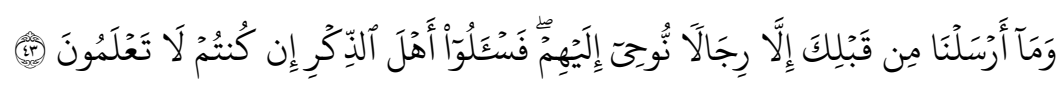

Artinya: "Dan Kami tidak mengutus sebelum kamu, kecuali orangorang lelaki yang Kami beri wahyu kepada mereka; maka bertanyalah kepada orang yang mempunyai pengetahuan jika kamu tidak mengetahui."

46 Abdul Karim Zaidan, Al-Wajiz (Jakarta: Pustaka al-Kautsar, 2013), 162. 
Sebab lain dalam persyaratan pembagian waris adalah belenggu otoritas harta waris peninggalan mayit berada pada pasangan yang ditinggal wafat atau dapat dikatakan pasangan yang ditinggal wafat serta merta merasa menguasai harta tersebut, tentu hal ini menyebabkan tertutupnya jalur perpindahan hak waris kepada ahli waris yang lain karena kunci kendali perpindahan hak waris hanya pada satu orang.

Hak kepemilikan atas harta benda dibedakan antara suami dan istri. Meski mereka tinggal dalam satu rumah dan membangun keluarga yang saling timbal balik dalam banyak hal. Namun khusus dalam masalah kepemilikan atas harta, masing-masing punya haknya sendiri-sendiri. Bila salah seorang dari mereka wafat, maka hanya harta yang dimilikinya saja yang dibagi waris. Adapun harta milik pasangannya tidak dibagi waris. Sebab pasangannya masih hidup, jadi hartanya tidak boleh dibagi waris.

Seorang pasangan tentu saja merupakan ahli waris dari pasangannya yang meninggal dunia. Namun selain pasangannya, anak-anak mayit termasuk ahli waris dan menempati kedudukan yang sama, yakni sama-sama menjadi ahli waris atas harta pasangannya dan ayah mereka. Apabila pasangan punya fara' waris, artinya dia punya keturunan yang mendapatkan warisan, maka bagian istri adalah $1 / 8$ dari harta peninggalan suami atau bagian suami ialah $1 / 4$ dari harta peninggalan istri. Sebagaimana pada QS. An-Nisa [4]: 12,

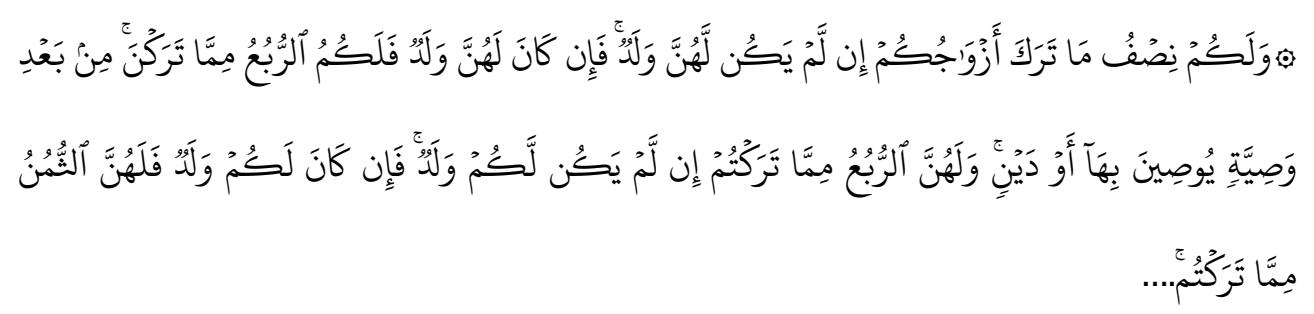

"Dan bagimu (suami-suami) seperdua dari harta yang ditinggalkan oleh isteriisterimu, jika mereka tidak mempunyai anak. Jika isteri-isterimu itu mempunyai anak, maka kamu mendapat seperempat dari harta yang ditinggalkannya sesudah dipenuhi wasiat yang mereka buat atau (dan) seduah dibayar hutangnya. Para isteri memperoleh seperempat harta yang kamu tinggalkan jika kamu tidak mempunyai anak. Jika kamu mempunyai anak, maka para isteri memperoleh seperdelapan dari harta yang kamu tinggalkan,..."

Maka hak seorang istri hanya $1 / 8$ dan hak seorang suami $1 / 4$ dari harta peninggalan masing-masing pasangan. Dengan demikian, seorang pasangan tidak boleh menjadi ahli waris tunggal dan satu-satunya. Terdapat beban kewajiban agar segera menyerahkan harta peninggalan pasangannya kepada anaknya, yaitu bagian yang memang menjadi hak anaknya. Jika pasangan mengambil semua harta almarhum pasangannya, jelas perbuatan itu haram, terlarang dan zalim. Dalam 
sabda Nabi n menjelaskan,

$$
\text { عن ابن عباس عن النبي صلى الله عليه وسلم قال: ألحقوا الفرائض بأهلها، فما بقي فهو لأولى رجل ذكر. }
$$

Artinya, "Dari Ibnu 'Abbas ra dari Nabi saw, beliau bersabda: berikanlah harta warisan (faraid) kepada orang-orang yang berhak menerimanya (menurut ketentuan). Bila masih ada sisa diberikan kepada saudara laki-laki terdekat." ${ }^{47}$

Penulis berpendapat bahwa harta waris dalam konteks masa digunakan salah satu atau beberapa ahli waris bukan sebuah penghalang untuk tidak dapat membagikan harta waris. Membagi harta waris itu tidak selalu identik dengan menjual harta kepada pihak lain dan membagikan uangnya.

Pada hakikatnya membagi waris merupakan penetapan siapa yang menjadi pemilik dari harta yang sebelumnya berstatus tidak bertuan. Hal ini lantaran tuannya telah meninggal dunia dan prinsipnya tidak boleh ada harta yang tidak bertuan. Apabila telah wafat tuannya, maka secara otomatis terjadi perpindahan kepada tuan berikutnya, yakni ahli waris yang masih hidup, di mana setiap ahli waris memiliki fard yang telah ditetapkan di dalam nas-nas syariah. Adapun pengertian waris menurut Ibnu 'Abidin dalam kitabnya, Hasyiyatu Ibnu 'Abidin tercatat sebagai berikut:

$$
\text { علم باصول من فقه وحساب تعرف حق كل في التركة }
$$

"Ilmu tentang dasar-dasar fiqih dan perhitungan, yang dengannya dapat diketahui hak-hak tiap orang dalam pembagian harta peninggalan." 48

Definisi di atas menerangkan bahwa ahli waris tidak menemukan urusan jual-menjual harta dalam hal pembagian waris, tetapi sekedar menetapkan hakhak setiap orang atas harta waris tersebut dengan kejelasan saham-saham kepemilikan setiap ahli waris. Maka Penulis menegaskan bahwa membagi harta warisan tidak berkaitan dengan penjualan harta, karena harta waris tidak selalu berbentuk rumah atau tanah. Harta waris bisa berbentuk apapun yang termasuk kategori harta, seperti uang, emas, hewan, kendaraan, surat-surat berharga, dan sebagainya. Dengan demikian harta tak berpemilik telah aman dari intrik perebutan dan perpecahan karena telah jelas kepunyaan siapa harta waris tersebut.

Selanjutnya beberapa contoh kasus penyelesaian pembagian waris

47 Muhammad bin 'Ismail bin Ibrahim bin al-Mugirah al-Bukhari, S/ahih Bukhari (Beirut: Dar anNajah, 1942), no. 6732, 150/8.

48 Ibnu 'Abidin, H\{a>syiyatu Ibnu 'A<bidi>n (Beirut: Da>rul Fikr, 1992), 499/5. 
menyangkut permasalahan ini. Contoh pertama, seorang meninggal dunia, meninggalkan ahli waris: istri, dua anak perempuan, seorang anak laki-laki, dan ibu dengan harta waris berupa rumah diatas tanah seluas $120 \mathrm{~m}^{2}$. Asal masalah dalam kasus ini adalah 24, dengan perincian: istri memperoleh bagian seperdelapan $(1 / 8)$ karena terdapat keturunan mayit, ibu mendapatkan seperenam $(1 / 6)$, serta dua anak perempuan dan seorang anak laki-laki memperoleh sisa harta peninggalan karena menjadi 'asabah bil gair. Dengan demikian istri memperoleh 3 saham, ibu memperoleh 4 saham, dan dua anak perempuan dan seorang anak laki-laki memperoleh sisa saham yakni 17 saham. Jika dijumlahkan keseluruhannya sebanyak 24 saham yang sesuai dengan akar masalah. Untuk membagi bagian dua anak perempuan dan seorang anak laki-laki maka perlu dilakukan pentashihan, yakni dengan membagi dengan jumlah per kepala maka akar masalah menjadi 96 dengan istri memperoleh 12 saham, ibu 16 saham, seorang anak perempuan memperoleh 17 saham jika dua anak perempuan maka menjadi 34 saham, dan seorang anak laki-laki memperoleh 34 saham. Setelah melalui perhitungan maka istri mendapat bagian tanah seluas $15 \mathrm{~m}^{2}$, ibu mendapat $20 \mathrm{~m}^{2}$ bagian tanah, setiap anak perempuan mendapatkan tanah seluas $21,25 \mathrm{~m}^{2}$, dan seorang anak laki-laki memperoleh bagian tanah seluas $42,50 \mathrm{~m}^{2}$, maka jumlah keseluruhan $120 \mathrm{~m}^{2}$ tanah.

Contoh kedua, seorang wafat meninggalkan ahli waris: suami dan anak laki-laki dengan harta waris sebuah rumah diatas tanah seluas $60 \mathrm{~m}^{2}$, jika dinominalkan tanah dan rumah tersebut bernilai 240 juta. Perincian pembagian ini ialah: suami mendapat seperempat (1/4), dan seorang anak laki-laki memperoleh sisa harta karena menjadi 'asabah bin nafsih dengan akar masalah yaitu 4. Maka suami memperolah 1 saham dan seorang anak laki-laki mendapat 3 saham. Jika dibagi dengan luas tanah maka suami memperoleh $15 \mathrm{~m}^{2}$ bagian tanah dan seorang anak tersebut mendapatkan $45 \mathrm{~m}^{2}$ bagian tanah. Sedangkan jika rumah tersebut laku terjual maka suami mendapatkan 60 juta dan anak laki-laki mendapat 180 juta.

Ketika telah jelas, maka dapat dikatakan harta peninggalan tersebut milik ahli waris secara bersama karena dalam bentuk yang utuh, tetapi dengan perbandingan nilai saham yang berbeda-beda dan tidak masalah harta peninggalan tersebut digunakan dengan kerelaan ahli waris sebagai pemilik saham tersebut. Maka pemenuhan syarat menunggu wafatnya pasangan suami dan istri agar pembagian waris dapat terlaksana dengan sebab harta peninggalan mayit masih dalam keadaan digunakan tidaklah sah menurut syariat. 
Sesungguhnya Allah l tiada membebani hamba-Nya dalam kerumitan aturan Islam, sebagaimana firman-Nya dalam QS. Al-Baqarah [2]: 286,

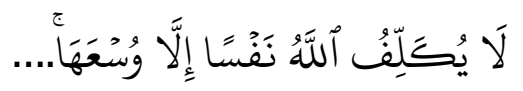

"Allah tidak membebani seseorang melainkan sesuai dengan kesanggupannya...."

Kebiasaan masyarakat yang melaksanakan persyaratan pembagian harta warisan setelah pasangan suami dan istri meninggal dunia dengan segala penyebabnya disebut juga tradisi atau adat, dalam pandangan Islam adat juga disebut dengan 'urf, yaitu apa-apa yang saling diketahui oleh manusia dan mereka mempraktikannya, baik perkataan, atau perbuatan, atau meninggalkan.

Dalam kamus ushul fiqih 'urf dijelaskan:

$$
\text { الشرعيين لا فرق بين العرف و العادة. }
$$

Artinya, "'Urf adalah apa yang dikenal oleh manusia dan berlaku padanya, baik berupa perkataan, perbuatan ataupun meninggalkan sesuatu. Hal ini juga dinamakan adat, dan dikalangan ulama syariat tidak ada perbedaan antara 'urf dan adat." 49

Hukum adat dalam pandangan Islam dapat dikemukakan sebagai berikut dalam qawa'id al-fiqhiyyah ada asas yang berbunyi:

$$
\text { المسلمون على شروطهم إلا شرطا حرم حلالا أو أحل حراما. }
$$

Artinya, "Kaum Muslim terikat dengan kesepakatan-kesepakatan yang mereka buat, kecuali kesepakatan yang mengharamkan yang halal atau menghalalkan yang haram)."50

Kaidah ini dirumuskan berlandaskan firman Allah swt dalam Q.S. Al-Nahl [16]: 90,

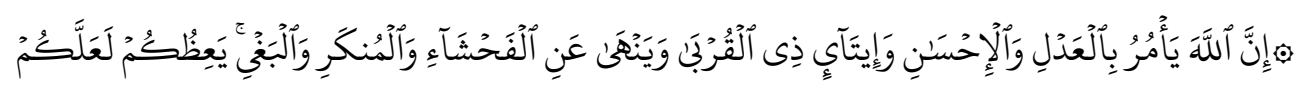

${ }^{49}$ Totok Jumantoro dan Samsul Munir Amin, Kamus Ilmu Us\{u>l Fiqih (Jakarta: Bumi Aksara, 2009),

50 Djazuli, Kaidah-Kaidah Fikih (Jakarta: Prenada Media Group, 2006), 33. 
"Sesungguhnya Allah menyuruh (kamu) berlaku adil dan berbuat kebajikan, memberi kepada kaum kerabat, dan Allah melarang dari perbuatan keji, kemungkaran dan permusuhan. Dia memberi pengajaran kepadamu agar kamu dapat mengambil pelajaran."

Lima penyebab di atas merupakan persetujuan atas wafatnya suami dan istri sebagai syarat pembagian waris yang tergabung dalam satu wadah kebiasaan persyaratan sesuai adat. Syarat pembagian warisan ini tertolak dalam kaidah ushul fiqih di atas karena termasuk dalam kategori 'urfal-fasid, yaitu adat yang berlaku di suatu tempat dengan pemerataan dalam pelaksanaan tetapi melanggar aturan maupun syariat yang telah ditetapkan oleh nash. Hal ini sangat tidak sesuai dan bertentangan dengan hukum waris Islam serta ketetapan-ketetapan yang telah ditentukan terkait tatacara pembagian waris. Pertentangan yang terjadi ialah antara 'urf dengan nash yang bersifat khusus dan rinci, yakni pertentangan yang di antara keduanya mengakibatkan tidak berfungsinya hukum yang terkandung dalam nash sehingga tidak bisa diterapkan hukum tersebut. 'Urf seperti ini tidak dapat dijadikan dalil syara', karena kehujjahan 'urf bisa diterima apabila tidak ada nash yang mengandung hukum permasalahan yang dihadapi.

Satu jalan yang dibenarkan tidak lain ialah aplikasi pembagian harta waris dengan syarat sesuai syariat Islam. Maka pada pendapat yang tidak menyetujui wafatnya suami dan istri sebagai syarat pembagian waris merupakan hal yang benar. Tiada kebolehan menahan harta waris bagi siapa pun jika salah seorang telah wafat tanpa ada nash yang membolehkan, maka Penulis sependapat dengan syarat pembagian waris ini. Dimana telah jelas disebutkan dalam Q.S. An-Nisa [4]: 12 ,

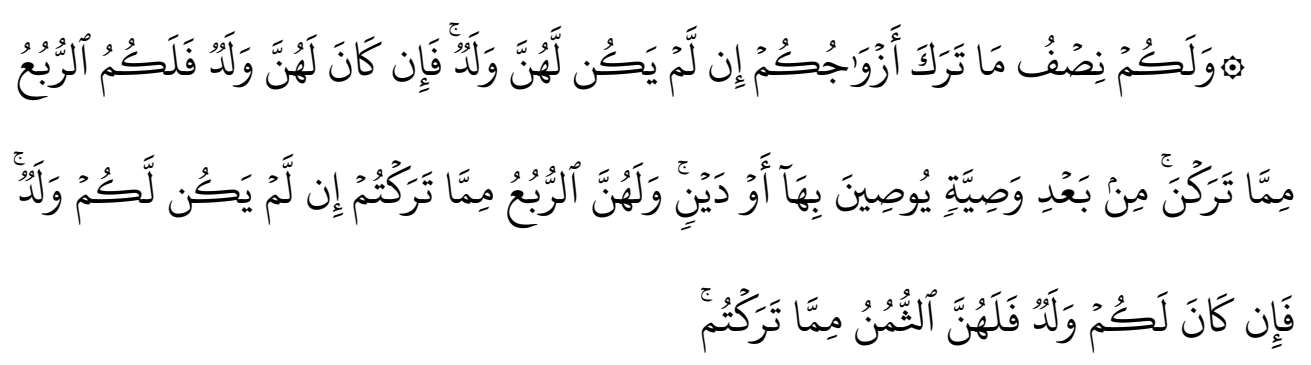

Penekanan katadan تركن posisi yang meninggalkan bagi yang ditinggalkan. Hal ini menjelaskan apabila seorang istri wafat antara meninggalkan anak atau tidak, maka bagi suami sekian dan begitu pun sebaliknya. Apabila seorang suami wafat antara meninggalkan anak atau tidak, maka bagian istri sekian. Dengan ini Penulis menarik kesimpulan, 
jika seorang meninggal baik suami atau istri, maka harta peninggalan dapat dibagi kepada ahli waris setelah kewajiban waris mayit ditunaikan.

Masalah syarat pembagian waris perlu diperhatikan secara seksama sesuai ketentuan hukum Islam. Jika dijalankan sesuai dengan syariat maka balasan pahala yang diperoleh sangatlah besar, tetapi jika diamalkan tidak sesuai aturan agama Islam, maka imbalan dosa pun tidak kalah besar. Firman Allah swt yang menjelaskan hal ini, yaitu Q.S. An-Nisa [4]: 14,

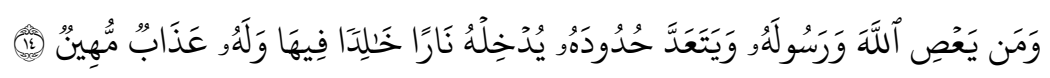

Islam yang agung telah menjelaskan dengan lengkap hukum-hukum yang berkenaan dengan masalah persyaratan pembagian waris ini, sehingga jika kaum muslimin ingin menekuni petunjuk Allah l dalam agama Islam maka semestinya mereka tidak akan terseret dalam penyimpangan-penyimpangan tersebut.

\section{A. Kesimpulan}

Pendapat masyarakat suku Muna yang berdomisili di Balikpapan Selatan mengenai syarat pembagian waris mterdapat dua klasifikasi. Pertama, beberapa diantaranya setuju bahwa wafatnya suami dan istri sebagai syarat pembagian waris suku Muna di Balikpapan Selatan karena adanya ketentuan adat yang mesti dilaksanakan, selain daripada itu bahwa terdapat manfaat yang akan diperoleh ahli waris dan keluarga, diantaranya tidak membebani dan memecah belah hubungan para ahli waris, serta bentuk penghormatan kepada salah satu pasangan yang ditinggal wafat. Kedua, beranggapan bahwa dalam pembagian waris bagi kaum muslimin sudah seharusnya melakukan sesuai hukum kewarisan dalam Islam. Oleh karena itu, hukum waris adat tidak dapat dijadikan rujukan atau pedoman dalam syarat pembagian harta peninggalan kepada seluruh ahli waris.

Menurut penulis, sistem pembagian waris suku Muna yaitu adanya penahanan pembagian waris karena perpindahan kepemilikan harta mengharuskan wafatnya salah satu pasangan yang ditinggal mati. Semestinya tetap menyegerakan dalam pembagian waris agar tidak tercampurnya harta pewaris satu dengan yang lainnya, serta setiap ahli waris mendapatkan haknya sesuai ketentuan syariat Islam. 


\section{Daftar Pustaka}

'Abidin, Ibnu 'Abidin, Hasyiyatu Ibnu. Beirut: Darul Fikr, 1992.

Abdullah, Sulaliman. Sumber Hukum Islam, Jakarta: Sinar Grafika, 1995.

Aen, H.A. Djazuli dan I. Nurul. Ushul Fiqih (Metode Hukum Islam), Jakarta: PT. Raja GrafindoPersada, 2000.

Al-'Utsaimin, Muhammad bin Shalih. Al-Ushul min 'Ilmil-'Ushul, trans. Ahmad S. Marzuqi, Yogyakarta: Media Hidayah, 2008.

Al-Azhar, Komite Fakultas Syariat Universitas. Ahkāmul Mawāris fil Fiqhil Islāmi, trans. Addys Aldizar dan Faturrahman, 20.

Al-Bukhari, Abu 'Abdillah Muhammad bin 'Ismail Sahih Bukhari, Beirut: an-Najah, 1442.

Al-Bukhari, Muhammad bin 'Ismail bin Ibrahim bin al-Mugirah. S/ahih Bukhari, Beirut: Dar an-Najah, 1942. No. 6732.

Al-Lahim, Abdul Karim ibn Muhammad. al-Faraidh, Saudi Arabia: Wizarat al-Syu'un al-Islamiyati wa al-Auqaf wa al-Da'wah wa al-Irsyad, 2000.

Al-Umam, Dian Khair. Fiqih Mawari\{s, Bandung: Pustaka Setia, 1999.

Amin, Totok Jumantoro dan Samsul Munir. Kamus Ilmu Ushul Fiqih, Jakarta: Bumi Aksara, 2009.

As-Sahabuni, Muhammad Ali. Al-Mawāris Fisy Syarī'ati; Islāmiyyah 'Alā Dhaul Kitāb was Sunnah, trans. A.M. Basalamah, Jakarta: Gema Insani Press, 1995.

Asy-Syaukani, Muhammad bin Ali bin Muhammad bin 'Abdillah bin al Husain. Nailul Autar Syarh Muntaqa al-Akhbar (Damaskus: Idarah at-taba'ah al-Munirah, n.d.), $4 / 53$.

At\{aillah, M. Fikih Waris Metode Pembagian Waris Praktis, Bandung: Penerbit Yrama Widya, 2018.

Aulia, Tim Redaksi Nuansa. Kompilasi Hukum Islam, 81.

Djazuli. Kaidah-Kaidah Fikih, Jakarta: Prenada Media Group, 2006.

Haroen, Nasroen. Ushul Fiqih I, Jakarta: Logos Wacana Ilmu, 1997.

Jawaz, Yazid bin 'Abdul Qadir. Prinsip Dasar Islam Menurut al-Quran dan as-Sunnah yang S/ahīh, Bogor: Pustaka At-Taqwa, 2005.

Khalaf, Abdul Wahab. Ilmu Ushul Fiqih, Bandung: Pustaka Setia, 2007.

Muslim, Imam. Sahih Muslim, Kairo: Darul Hadits, 2001.

Parman, Ali. Kewarisan Dalam al-Quran (Suatu Kajian Hukum Dengan Pendekatan Tafsir Tematik, Jakarta: Raja Grafindo Persada, 1995.

Rofiq, Ahmad. Fikih Mawaris\{, Depok: PT. Raja Grafindo Persada, 2000. 
Sarwat, Ahmad. Seri Fiqih Kehidupan: Mawāris, Jakarta: Rumah Fiqih Publishing, 2017.

Suparman, Eman. Hukum Waris Indonesia, Bandung: PT. Refika Aditama, 2007.

Syarifuddin, Amir. Ushul Fiqih, Jakarta: Logos Wacana Ilmu, 2001.

Zahro, Abu. Ushul Fiqih, Jakarta: Pustaka Firdaus, 2911.

Zaidan, Abdul Karim. Al-Wajiz, Jakarta: Pustaka al-Kautsar, 2013

Zein, Satria Efendi dan M. Ushul Fiqh, Jakarta: Kencana, 2005. 